\title{
Vector Auto Regression Model of Inflation in Mongolia
}

\section{Taivan Ulziideleg*}

Senior Supervisor, Supervision Department, Bank of Mongolia (the Central Bank), Ulaanbaatar, Mongolia

\begin{abstract}
This paper investigates the relationship between inflation, real money, exchange rate and real output based on data from 1997 to 2005 . Vector auto regression analysis presented to establish the relationship. The results of the research indicate that the dynamics of inflation are affected by previous month exchange rate changes and money growth. It means that there is a need to lessen the influence of exchange rate expectation on economy and to improve efficiency of management of the monetary instrument.
\end{abstract}

Keywords: Inflation; Monetary; Consumption; Management; Economy

\section{Introduction}

When discussing the causes of inflation in developing countries one finds that the literature contains two major competing hypotheses. First, there is the monetarist model, which sees inflation as a monetary phenomenon, the control of which requires a control of the money supply as a necessary and sufficient condition such that it grows at a rate consistent with the growth of demand for money with stable prices. The monetarist model is predicated upon the existence of a stable demand for money. An existence of stable demand for money in Mongolia itself might be a disputable proposition due to the numerous deep structural changes and banking crises, which are underway within Mongolian economy since 1990 [1].

Second, non-monetary approach argues that there are non-monetary causes of inflation. These causes featured structural characteristics. Ghatak and Sánchez-Fung [1] demonstrated that there are following structural characteristics. First, the relative inelasticity supply of food in developing countries. The supply of essential food commodities may lag behind the demand causing food prices to rise. This characteristic would be observed in Mongolia. For instance, meat price fluctuations were one of the major changes in the CPI index and those meat price ups and downs were a consequence of seasonal shortages in meat supply during spring and early months of summer when the Mongols consider the meat to be leanest and therefore unsuitable for delivery and consumption. Second, the lack of internal financial resources as a distinctive group of reasons causing inflation. The shortage of government funding in the sphere of infrastructure is usually solved by inflationary consequences. Third, cost inflation, which is derived by the increase in price of production factors, including electricity [2].

Many models set up in sphere of monetarist approach. Rani [3] run regression between the broad and narrow money aggregates and the inflation rates in India and found that relationship is statistically significant. He used Ordinary least square method (OLS). Paul and Bhanumurthy [4] employ the Vector autro regression (VAR) model to investigate relationship between the money supply and price in India and found the money-price relationship exists within that period and is very strong when money aggregate $M 3$, which includes time deposits, is used supporting the monetarist notion of exogenous money supply and the impact of money on prices.

Brada and Kutan [5] used F-tests of running nominal broad money, nominal average wages, and import prices in form of the exchange rate adjusted German whole sale index on the Consumer price index (CPI) in Hungary, Poland and Czech Republic for the period over 1990-1998 to investigate the determinants of inflation in those countries. They show that foreign prices and the persistence of inflation were the key elements of inflation.

Kalra [6] studies inflation and money demand in Albania, which is a small transition economy the size of Mongolia in terms of GDP between 1993-1997. His model supports the claim that determinants of inflation and money demand in transition economies are similar to those in market economies. In particular, for the long run, he establishes a positive relationship between the price level and the exchange rate.

Although, considerable research has been conducted to identify the factors that influence inflation in transition economies, there has been much less effort in identifying the relationship between these factors and inflation in Mongolia. A question remains how these factors play a role in explaining of inflation. The objective of this study is to examine the impact of the real money supply, real output and exchange rate movements on price.

The results of the research indicate that the dynamics of inflation are affected by previous month's exchange rate changes and money growth. It means that there is a need to lessen the influence of exchange rate expectation on instrument. The paper is structured as follows. Section 1 investigates the nature of Mongolian inflation. Section 2 gives the methodology. Section 3 gives the results of the stationary test and econometric estimation, including, autocorrelation test, heteroskedasticity test and Granger Sims F test. Section 4 gives the VAR analysis. Section 5 gives the discussion and conclusion.

\section{Inflation of Mongolia}

Similar to other transition economies, Mongolia's relative prices were badly distorted, therefore, the variety of prices, mostly those of energy, food, utilities and rents were taken out of the government control and rapidly liberalized during the first years of reform. Also, there were major fiscal imbalances due to the extensive but unsustainable

*Corresponding author: Ulziideleg T, Senior Supervisor, Supervision Department, Bank of Mongolia (the Central bank), Ulaanbaatar, Mongolia, Tel: + 976-11-327093; E-mail: taivan@mongolbank.mn

Received November 14, 2017; Accepted December 01, 2017; Published December 08, 2017

Citation: Ulziideleg T (2017) Vector Auto Regression Model of Inflation in Mongolia. Empirical Evidence from Europe. Bus Eco J 8: 330. doi: 10.4172/21516219.1000330

Copyright: @ 2017 Ulziideleg T. This is an open-access article distributed under the terms of the Creative Commons Attribution License, which permits unrestricted use, distribution, and reproduction in any medium, provided the original author and source are credited. 
social expenditure. These imbalances, whose true size was masked by the lack of transparency in public sector accounts, were exacerbated by the early phases of reform, including wage adjustments, price liberalization, exchange rate devaluation. As a result, governments in transition economies have been relatively unwilling to make unpopular decisions to reduce fiscal deficits, which, in turn, acted as the "motor of inflation". Moreover, Mongolia is an open and small economy. The openness of its economy motivates the inclusion of the exchange rate movements of Mongolian to grog against US dollar. An assumption is that the togro's depreciation may increase the inflation rate, because the depreciation imports inflation from abroad.

The inflation rate in Mongolia declined dramatically from a peak of 325.5 per cent in 1992 to 11 and 9.5 per cent in 2004 and 2005, respectfully (Figure 1).

\section{Data}

In this study monthly statistical data are used. In 1996 and 1998 there were banking crises in Mongolia and as a result three major banks were liquidated. In his research, Frecaut and Sidgwick [7] show that Mongolian banks liquidity worsening resulted in some part of the money supply has been lost the negative financial intermediation. Therefore, in order to reduce this negative impact, data from the December 1998 to December 2005 are used in estimations.

\section{Variables}

Inf: inflation, beginning from the year; Inf0: inflation based on monthly changes; CPI: Consumer Price Index;

M/P: real money supply (M2/CPI); S: spot rate USD/ togrog; Y: nominal GDP; Y/P: Real output (GDP/CPI)

\section{Methodology}

The price level is assumed to be a weighted average of tradable $\left(\mathrm{P}_{\mathrm{Tt}}\right)$ and non-tradable $\left(\mathrm{P}_{\mathrm{NTt}}\right)$ and the price of tradable is determined by the exchange rate $(\mathrm{St})$ and foreign price $\left(\mathrm{P}^{\star} \mathrm{t}\right)$ :

$$
\mathrm{P}_{t}=\mathrm{P}_{\mathrm{Tt}}^{\phi} \mathrm{P}_{\mathrm{NTt}}{ }^{(1-\phi)}, 0<\phi<1, \Rightarrow \log \left(\mathrm{P}_{\mathrm{t}}\right)=\phi \log \mathrm{P}_{\mathrm{Tt}}=(1-\phi) * \log \mathrm{P}_{\mathrm{NTt}}
$$

Where, $\phi$ is the share of tradable in total expenditure. For simplicity, $\phi$ is assumed constant.

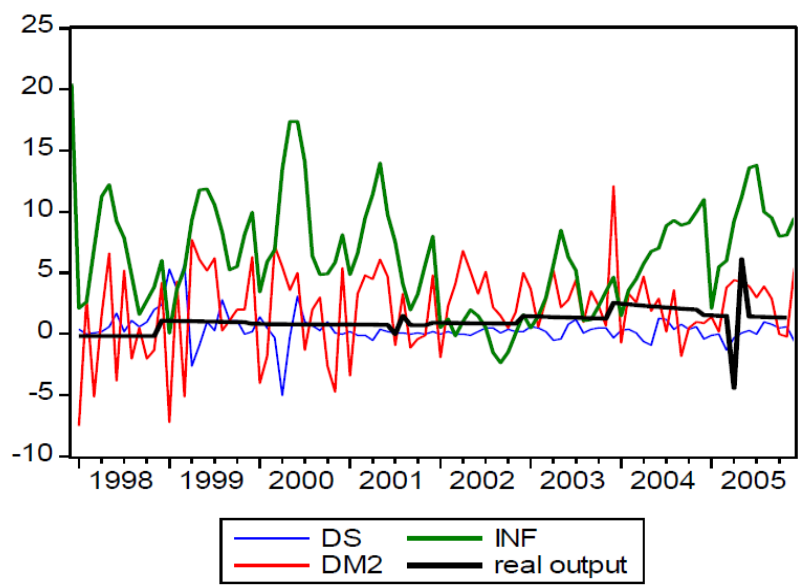

Source: Bank of Mongolia, 2005. http://www.mongolbank.mn/ (2006/03/10).

Figure 1: Movements in $M 2$, exchange rate, inflation and real output in Mongolia (percentage)

$$
\mathrm{P}_{\mathrm{Tt}}=\mathrm{S}_{\mathrm{t}} \mathrm{P}_{\mathrm{t}} * \Rightarrow \log \mathrm{P}_{\mathrm{Tt}}=\log \left(\mathrm{S}_{\mathrm{t}}\right)+\log \left(\mathrm{P}_{\mathrm{t}}^{*}\right)
$$

Eqn. (2) suggests that the price of tradable in domestic currency may change in response to a change either in the exchange rate or in the price of tradable in foreign currency or both. When the exchange rate remains fixed, the price of tradable in domestic currency changes with the change in the price of tradable in foreign currency may change when the exchange rate changes with or without a change in the price of tradable in foreign currency. For simplicity, $\mathrm{P}_{\mathrm{t}}^{*}$ is normalized unity. Then eqn. (2) is written as:

$$
\log \mathrm{P}_{\mathrm{Tt}}=\log \left(\mathrm{S}_{\mathrm{t}}\right)
$$

We assume that the price of non-tradable changes in response to disequilibrium in the money market [8]. Within a flow disequilibrium in the money market, the price of non tradable may then change in response to the discrepancy between the log difference of actual real balances at the beginning of the period $\left(\Delta \operatorname{logm}_{\mathrm{t}-\mathrm{i}}\right)$ and the log difference of real balances that individuals desire to hold at the end of the period $\left(\Delta \log \mathrm{m}_{\mathrm{t}}^{\mathrm{d}}\right)$, such that:

$$
\log \mathrm{P}_{\mathrm{NT}}-\log \mathrm{P}_{\mathrm{NTt}-1}=\gamma\left(\Delta \log \mathrm{m}_{\mathrm{t}-1}-\Delta \log \mathrm{m}_{\mathrm{t}}^{\mathrm{d}}\right)+\mathrm{u}_{\mathrm{t}}
$$

where $\mathrm{m}=\mathrm{M} / \mathrm{P},(\gamma$ is the coefficient of adjustment, whose value is expected to lie between zero and unity; $\mathrm{u}$ is a random error term with zero mean and a constant variance. Eqn. (3) shows that only a proportion $(\gamma)$ of disequilibrium in the money market is eliminated between periods $\mathrm{t}-1$ and $\mathrm{t}$.

Take the first order log differences of eqns. (1) and $\left(2^{2 e}\right)$, such that:

$$
\begin{aligned}
& \log \left(\mathrm{P}_{\mathrm{t}} / \mathrm{P}_{\mathrm{t}-1}\right)=\phi \log \mathrm{P}_{\mathrm{Tt}} / \mathrm{P}_{\mathrm{Tt}-1}+(1-\phi) * \log \mathrm{P}_{\mathrm{NTt}} / \log \mathrm{P}_{\mathrm{NTt}-1} \\
& \log \left(\mathrm{P}_{\mathrm{Tt}} / \mathrm{P}_{\mathrm{Tt}-1}\right)=\log \left(\mathrm{S}_{\mathrm{t}} / \mathrm{S}_{\mathrm{t}-1}\right)
\end{aligned}
$$

Substitution of eqns. (3) and (5) into eqn. (4), following is yields:

$$
\log \left(\mathrm{P}_{\mathrm{t}} / \mathrm{P}_{\mathrm{t}-1}\right)=\phi \log \left(\mathrm{S}_{\mathrm{t}} / \mathrm{S}_{\mathrm{t}-1}\right)+(1-\phi) \gamma\left(\Delta \log \mathrm{m}_{\mathrm{t}-1}-\Delta \operatorname{logm}_{\mathrm{t}}^{\mathrm{d}}\right)+(1-\phi) \mathrm{u}_{\mathrm{t}}
$$

For simplicity, the demand for money is represented as a function of the level of real income (y):

$$
\mathrm{m}_{\mathrm{d}}=\mathrm{f}(\mathrm{y}) \Rightarrow \Delta \operatorname{logm}_{\mathrm{t}}^{\mathrm{d}}=\beta_{0}+\beta_{1} * \Delta \log \mathrm{y}_{\mathrm{t}}
$$

Substitution of eqn. (7) into (6), after manipulations, yields:

$$
\begin{aligned}
& \log \left(\mathrm{P}_{\mathrm{t}} / \mathrm{P}_{\mathrm{t}-1}\right)=-(1-\phi) \gamma \beta 0+\phi \log \left(\mathrm{S} / \mathrm{S}_{\mathrm{t}}\right)+(1-\phi) \gamma \Delta \log \mathrm{M}_{\mathrm{t}-1}- \\
& (1-\phi) \gamma\left(\Delta \log \mathrm{P}_{\mathrm{t}-1}\right)-(1-\phi) \gamma \beta 1 \Delta \log y_{t}+(1-\phi) u_{t}
\end{aligned}
$$

In reduced form, eqn. (8) would be:

$\log \left(\mathrm{P}_{\mathrm{t}} / \mathrm{P}_{\mathrm{t}-1}\right)=\theta_{1}+\theta_{2} \log \left(\left(\mathrm{M}_{\mathrm{t}-1} / \mathrm{P}_{\mathrm{t}-1}\right) /\left(\mathrm{M}_{\mathrm{t}-2} / \mathrm{P}_{\mathrm{t}-2}\right)\right)+\theta_{3} \log \left(\mathrm{S} / \mathrm{S}_{\mathrm{t}-1}\right)+\theta_{4} \log \left(\left(\mathrm{Y}_{\mathrm{t}} / \mathrm{P}_{\mathrm{t}}\right) /\left(\mathrm{Y}_{\mathrm{t}} / \mathrm{P}_{\mathrm{t}-1}\right)\right)+\theta_{5}$ Where $\theta_{1}=-(1-\phi) \gamma \beta_{0}, \theta_{2}=(1-\phi) \gamma, \theta_{3}=\phi, \theta_{4}=(1-\phi) \gamma \beta_{1}, \theta_{5}=(1-\phi) \mathrm{u}_{1}$

Eqn. (9) shows that inflation depends on change in exchange rate, real output of the current period and real money supply. These factors not only influence inflation, but also each other. For example, if an exchange rate appreciates, depositors will rise foreign currency deposits while might reduce domestic currency deposits, and consequently M2.

\section{Results of Stationary Test}

Initially, the time series properties of data examined before estimating the regression. Key concepts are the ideas of stationary, non-stationary and con-integrability of economic series. For example, if variables are non-stationary, then shocks to the level of each variable produce permanent shifts. On the other hand, if time series are stationary, then shocks will tend to die off and the time series will revert to their mean values. Regressing two non-stationary series on each other may create problem of spurious regression, refers to the situation where correlation is found to be present between the ratios of 
Citation: Ulziideleg T (2017) Vector Auto Regression Model of Inflation in Mongolia. Empirical Evidence from Europe. Bus Eco J 8: 330. doi: 10.4172/2151-6219.1000330

Page 3 of 5

variables even tough the original variables are uncorrelated or random. Therefore, the time series properties of data need to be examined.

Appendix A shows dynamics of variable. The fluctuation shown in the CPI and real output graph is related to that base year was changed in CPI calculation. Table 1 shows result of the stationary test.

Table 2 shows that inf, inf0 is $\mathrm{I}(0)$ at 1 per cent level significance. Also, it shows that CPI, M2, Y and S are I(1) at 1 per cent level of significance. There are two versions of analysis dealing with nonstationary data: regression based on transforming to stationary data through its difference; and, co-integration analysis. In this study, the first order difference is used.

\section{Test for autocorrelation}

From the regression, we see that $\mathrm{DW}=2.15$. The result might us suspect that there is an autocorrelation in model. This phenomenon means that the error terms are interrelated - that is, prior error information influences the value of the current error term. The current error term can be written as some function of previous error terms:

$$
u_{t}=\alpha u_{t-1}+v_{t}
$$

Thus, for more precise we will look at the residual's graph: To avoid some pitfalls of the Durbin-Watson statistic test, we apply the Breusch Godfrey statistic. Under the null hypothesis of no serial autocorrelation: $\mathrm{H}_{0}: \rho_{1}=\rho_{2}=0$, then we now calculate the BG:

$(n-p) R^{2} \approx X_{p}^{2}$ based on our output of BG serial autocorrelation (Appendix B).

\section{$(\mathrm{n}-\mathrm{p}) R^{2}=(95-1)^{\star} 0.006308=0.5929$.}

Choose $\alpha=5 \%$, we have $x_{1}^{2}=18.5476>(n-p)^{\star} R^{2}=0.5929$, thus, we fail to reject the null hypothesis of no serial autocorrelation.

\section{Test for heteroscedasticity}

An important assumption of the classic linear regression model is that the variance of each disturbance term $U_{i}$, conditional on the chosen values of the explanatory variables, is some constant number equal to $\sigma^{2}$. Symbolically, it is can be expressed as:

$$
E\left(u_{i}^{2}\right)=\sigma^{2}, i=1,2,3 \ldots \ldots . . n
$$

With this assumption of homoskedasticity, our OLS will be BLUE. Thus, to test whether the model satisfies the assumption or not, heteroskedasticity is checked. This phenomenon is that the conditional variance of $\mathrm{Y}_{\mathrm{i}}$ is not a constant. It increases as explanatory Xij increases that means:

$$
E\left(u_{i}^{2}\right)=\sigma_{i}^{2}, i=1,2,3 \ldots \ldots . n
$$

Actually, if our model is heteroskedasticity, it may cause problems such as unbiased estimating of coefficients of explanatory variables, unnecessarily larger confidence interval. As consequence, a result of t-test and F-test will statistically be incorrect. To cope with the problem, White's general heteroskedasticity test can be employed to test whether there is heteroskedasticity in the data.

\section{White's general heteroskedasticity test}

This method requires reordering the observations with respect to the $\mathrm{X}$ variable that supposedly caused heteroskedasticity. Generally, it is widely used as it does not rely on the normality assumption and is easy to implement. By applying the method to the residuals obtained from regression, we have the following result:

Under the null hypothesis that there is no heteroskedasticity, we

\begin{tabular}{|c|c|c|c|c|c|c|c|c|c|c|c|c|}
\hline \multirow[t]{3}{*}{ Indicators } & \multicolumn{4}{|c|}{ No difference } & \multicolumn{4}{|c|}{1 level } & \multicolumn{4}{|c|}{2 level } \\
\hline & \multirow[t]{2}{*}{ ADF } & \multicolumn{2}{|c|}{ Test crit.value } & \multirow[t]{2}{*}{$\mathrm{Y} / \mathrm{N}$} & \multirow[t]{2}{*}{ ADF } & \multicolumn{2}{|c|}{ Test crit.value } & \multirow[t]{2}{*}{$\mathrm{Y} / \mathrm{N}$} & \multirow[t]{2}{*}{ ADF } & \multicolumn{2}{|c|}{ Test crit.value } & \multirow[t]{2}{*}{$\mathrm{Y} / \mathrm{N}$} \\
\hline & & $1 \%$ & $5 \%$ & & & $1 \%$ & $5 \%$ & & & $1 \%$ & $5 \%$ & \\
\hline $\mathrm{CPI}$ & -1.85 & -4.06 & -3.46 & $\mathrm{~N}$ & -10.14 & 4.06 & -3.46 & $Y^{*}$ & & & & \\
\hline Inf & -4.71 & -3.5 & -2.89 & $Y^{*}$ & & & & & & & & \\
\hline Inf0 & -7.6 & -3.5 & -2.89 & $\mathrm{Y}^{*}$ & & & & & & & & \\
\hline M2 & 0.26 & 4.06 & 3.46 & $\mathrm{~N}$ & -4.16 & 3.5 & -2.89 & $\mathrm{Y}^{*}$ & & & & \\
\hline$S$ & 2.29 & 4.06 & 3.46 & $\mathrm{~N}$ & -7.03 & 3.5 & -2.89 & $\mathrm{Y}^{*}$ & & & & \\
\hline $\mathrm{Y}$ & 0.8 & -4.06 & -3.46 & $\mathrm{~N}$ & -13.4 & 4.06 & -3.46 & $\mathrm{Y}^{*}$ & & & & \\
\hline \multicolumn{13}{|c|}{$\begin{array}{l}\text { Y: means data is stationary; } \mathrm{N} \text { : means data is non stationary; } \\
\text { *shows data is stationary at } 1 \% \text { of significance; } \\
\text { ** Shows data is stationary at } 5 \% \text { of significance. } \\
\text { Source: Bank of Mongolia, } 2005 \text {. http://www.mongolbank.mn/ }(2\end{array}$} \\
\hline
\end{tabular}
have $n * \mathrm{R}^{2}$ follows the $x_{d f}^{2}$ distribution:

$$
n * R^{2} \sim x_{d f}^{2}=0.111 * 95=10.545
$$

\begin{tabular}{|c|c|c|c|c|}
\hline \multicolumn{5}{|l|}{ White Heteroskedasticity Test } \\
\hline F-statistic & 1.829562 & Probability & & 0.102404 \\
\hline Obs*R-squared & 10.53625 & Probability & & 0.103811 \\
\hline Variable & Coefficient & Std. Error & t-Statistic & Prob. \\
\hline C & -13.50217 & 4.313256 & -3.13039 & 0.0024 \\
\hline \multirow{2}{*}{$\begin{array}{l}\mathrm{LOG}\left(\mathrm{M} 2(-1)^{\star} \mathrm{CPI}(-2)\right) /\left(\mathrm{M} 2(-2)^{*} \mathrm{CPI}(-1)\right)\left(\mathrm{LOG}\left(\mathrm{M} 2(-1)^{*} \mathrm{CPI}(-2)\right) /\right. \\
\left.\left(\mathrm{M} 2(-2)^{\star} \mathrm{CPI}(-1)\right)\right)^{\wedge} 2\end{array}$} & 752721.2 & 284534.2 & 2.645451 & 0.0097 \\
\hline & $-9.58 \mathrm{E}+11$ & $3.62 \mathrm{E}+11$ & -2.6469 & 0.0096 \\
\hline $\operatorname{LOG}(\mathrm{S} / \mathrm{S}(-1))$ & -0.264644 & 0.498223 & -0.53118 & 0.5966 \\
\hline$(\operatorname{LOG}(\mathrm{S} / \mathrm{S}(-1)))^{\wedge} 2$ & -1.108064 & 12.22326 & -0.09065 & 0.928 \\
\hline $\operatorname{LOG}\left(\mathrm{Y}^{\star} \mathrm{CPI}(-1) / \mathrm{Y}(-1)^{\star} \mathrm{CPI}\right)$ & 2.672177 & 0.855106 & 3.124966 & 0.0024 \\
\hline$\left(\mathrm{LOG}\left(\mathrm{Y}^{*} \mathrm{CPI}(-1) / \mathrm{Y}(-1)^{\star} \mathrm{CPI}\right)\right)^{\wedge} 2$ & -0.13295 & 0.04259 & -3.12162 & 0.0024 \\
\hline R-squared & 0.110908 & Mean dependent var & & 0.00715 \\
\hline
\end{tabular}

Table 1: Result of stationary test.

Table 2: Result of general heteroskedasticity test. 
Choose the critical chi_square value for $6 \mathrm{df}$, we have: for $5 \%$, $x_{d f=5}^{2}=12.59>\mathrm{n}^{\star} \mathrm{R}^{2}$, for $10 \%, x_{d f=5}^{2}=10.65>\mathrm{n}^{\star} \mathrm{R}^{2}$.

Thus, for all practical purposes, we can conclude that there is no heteroskedasticity in the data.

\section{Granger Sim's causality test}

The theory says that there is the relationship between the factors that influence inflation. To test the hypothesis whether the change in M2 and exchange rate cause inflation, the Granger causality test is done. This can be carried out, if variables are time series. At the case that variables are I(1) or I(2), The Granger causality test should be carried out through variables"e first or second level difference, respectively. Table 3 shows the results of the Granger Sims F test.

The results consistent with the theoritical expectation. Table 3 shows that the null hypothesis that M2 growth does not cause inflation would not be rejected in all cases except when the estimation included 13 months lag. In other words, the Granger-Sims causality test says that the changes in M2 cause changes in the CPI in Mongolia. Similarly, the null hypothesis that the exchange rate changes cannot be cause of inflation would not be rejected in all cases except when the estimation included 12 month lag. When inflation is measured by monthly changes basis, the null hypothesis that exchange rate changes cannot be cause of inflation would not be rejected in all cases except when the estimation included 3 and 9 month lag.

\section{Vector auto regression model}

In order to evaluate the feasibility of using inflation targeting, or even of more traditional and backward-looking approaches to monetary policy, in these transition economies, we estimate a vector autoregressive (VAR) model of the price level. This model shows which causal factors are the most important sources of continuing inflation and thus feasibility of reducing inflation by means of monetary policy. A VAR is an $n$-eqn. $n$-variable linear model in which each variable is in turn explained by its own lagged values, plus current and past values of the remaining $n-1$ variables. This simple frame work provides a systemic way to capture rich dynamics in multiple time series. As Sims [9] and others argue, VARs hold out the promise of providing a coherent and credible approach to data description, forecasting, structural inference and policy analysis [10]. From eqn. (9), following system can be derived. The system of eqns. is estimated using Eviews 5.0.

$$
\begin{aligned}
& \mathrm{Y}_{\mathrm{t}}=\theta+\sum_{i=1}^{p} A_{i} Y_{t-i}+u_{t} \\
& Y_{t}=\left[\begin{array}{c}
d \log P_{t} \\
d \log \left(S_{t}\right) \\
d \log \left((M 2 / P)_{t}\right) \\
d \log \left((Y / P)_{t}\right)
\end{array}\right] \theta=\left[\begin{array}{c}
\theta_{1} \\
\theta_{2} \\
\theta_{3} \\
\theta_{4}
\end{array}\right] A_{i}=\left[\begin{array}{llll}
\theta_{11, i} & \theta_{12, i} & \theta_{13, i} & \theta_{14, i} \\
\theta_{21, i} & \theta_{22, i} & \theta_{23, i} & \theta_{24, i} \\
\theta_{31, i} & \theta_{32, i} & \theta_{33, i} & \theta_{34, i} \\
\theta_{41, i} & \theta_{42, i} & \theta_{43, i} & \theta_{44, i}
\end{array}\right] u_{t}=\left[\begin{array}{c}
u_{1 t} \\
u_{2 t} \\
u_{3 t} \\
u_{4 t}
\end{array}\right]
\end{aligned}
$$

Here, Pt is CPI and $\mathrm{u}$ is stochastic error term. Variables for VAR are log functions in exchange rate, real output, real money supply and inflation. Akaike and Schwartz criterion were chosen in determination of the lag length. Estimation is made in case of 2-12 months lag lengths. In compliance with this criterion, system with lag length 8 will be preferred [11-13].

The result of the system indicates that previous 1 and 2 months inflation negatively influences inflation. Rise in previous 2-4 months real money supply positively influence inflation. However, the growth in the nominal exchange rate of previous 1 and 2 months negatively influence inflation. Change in real output of previous 3 and 4 months influence positively on current inflation (Appendix C).

The impulse response function is shown in Appendix D. This function says influence of change in M2 on inflation is stronger than the influence of the exchange rate.

\section{Discussion}

Based on the econometric techniques, some tests have been done taking into account of the inflation model. The eqn. shows that inflation is strongly affected by exchange rate and money growth changes. Changes inflation of the prior period also has a significant impact on current inflation, but this effect takes longer to work its way through the economy than money supply and exchange rate changes. The model points to a dominant role of monetary policies in the behaviour of inflation and shows a low persistence of inflation in Mongolia. Both factors contributed to the observed behaviour of inflation.

\section{Conclusion}

Our results are based on real money, real output, exchange rate and CPI data from 1997-2005. The econometric results show that it is feasible to estimate robust money supply, exchange rate, and real output and inflation eqns. for Mongolia. The model expresses inflation as a function of money, the exchange rate and real output. In fact, the dynamics of inflation are affected by previous month exchange rate changes and money growth. It means that Central bank should make arrangements to reduce dollarization to lessen the influence of exchange rate expectation on economy and to improve efficiency of management of the monetary instrument.

In addition, in order to have effective management of money supply, the development of money market should be accelerated. The money market development will not only contribute to controlling inflation, but also it will contribute to effective allocation of the resources and channelling of money into real economy. Consequently, it would assist the economic growth. Finally, the estimation of the model may have some errors. It is due to possibility to get a good econometric

\begin{tabular}{|c|c|c|c|c|}
\hline \multicolumn{5}{|c|}{ Inflation beginning from the year } \\
\hline No & Ho hypothesis & P-value & Ho hypothesis & P-Value \\
\hline \multicolumn{5}{|c|}{ Monthly changes /M2-Inflation/ } \\
\hline$m=13$ & M2 growth does not cause inflation & 0.07 & Inflation does not cause M2 growth & 0.05 \\
\hline$m=14$ & The change M2 does not cause the inflation & 0.065 & Inflation does not cause change in $\mathrm{M} 2$ & 0.03 \\
\hline \multicolumn{5}{|c|}{ Monthly changes /Exchange rate-Inflation/ } \\
\hline$m=12$ & The change in exchange rate does not cause inflation & 0.01 & Inflation does not cause the change in exchange rate & 0.94 \\
\hline \multicolumn{5}{|c|}{ Monthly changes /Exchange rate-Inflation/ } \\
\hline$m=3$ & The change in exchange rate does not cause inflation & 0.00036 & Inflation does not cause the change in exchange rate & 0.00036 \\
\hline $\mathrm{m}=9$ & The change in exchange rate does not cause inflation & 0.00226 & Inflation does not cause the change in exchange rate & 0.00016 \\
\hline
\end{tabular}
estimation may be constrained. In the future, there is necessity to

Table 3: Result of Granger Causality Test. 
Citation: Ulziideleg T (2017) Vector Auto Regression Model of Inflation in Mongolia. Empirical Evidence from Europe. Bus Eco J 8: 330. doi: 10.4172/2151-6219.1000330

continue estimation, using experience and achievements in research work done by foreign scholars.

\section{References}

1. Ghatak S, Sánchez-Fung JR (2007) Monetary economics in developing countries. Palgrave macmillan.

2. Kirkpatrick $\mathrm{CH}$, Nixson FI (1976) The origins of inflation in less developed countries: a selective review. Manchester University Press.

3. Rani PG (1999) Inflation in India: whether classical or non-classical. The Indian Economic Journal 47: 110.

4. Paul MT, Bhanumurthy NR (1999) Money supply, output and price leve relationship in India. The Indian Economic Journal 47: 42.

5. Brada JC, Kutan AM (2002) The end of moderate in three transition economies? William Davidson Institute Working Paper Number 433.
6. Kalra MS (1998) Inflation and money demand in Albania. IMF working paper.

7. Frecaut O, Sidgwick E (1998) Systemic banking distress: The need for an enhanced monetary survey. IMF working paper.

8. Hossain MMA (2002) Exchange rate responses to inflation in Bangladesh. IMF Working paper.

9. Sims CA (1980) Macroeconomics and reality. Econometrica 48:1-48.

10. Stock JH, Watson MW (2001) Vector autoregression. The Journal of Economic Perspectives 15: 101-115.

11. Gujarati DN (2004) Basic econometrics. Massachusetts.

12. Parkin M, Zis G (1976) Inflation in open economy. Manchester University Press.

13. Walsh CE (2004) Monetary theory and policy. Second edition, MIT press. 